\title{
English summaries
}

The Image of Lenin in Revolutionary Iconography

Fr.-X. CoQuin

In destroying effigies of the tzar and symbols of autocracy, the February 1917 revolution created a void which would have to be filled sooner or later. October 1917: intending to make art serve the revolution the new Soviet leaders hastened to launch a huge "monument propaganda" program to commemorate revolutionary celebrities of the past, and later of the present as well. The President of the new Soviet government, indifferent for a long time to any form of personal publicity, couldn't indefinitely escape the attention of artists; thus right from the first months of the October revolution, photographers, drawers, poster artists and sculptors adopted the image of the number one Bolshevik, portraying him in a wide variety of ways. This article sets out to analyze the different competing representations from which emerged, in the end, the figure of the prophet guiding humanity in its march towards a radiant socialist future. A few years later, "camarade Il'ic's death, along with the tenth anniversary of the October revolution, gave definitive form to this emblematic image which synthesized in its own way the many roles filled by the founding hero of the new Soviet State. The time was right for a massive distribution of realist effigies of Lenin, whose cult was less than ever fortuitous.

\section{Class Identity in NEP Society}

S. FITZPATRICK

For the Bolsheviks, being Marxists, class was the basis of social analysis and the conceptual tool with which to understand the political balance of forces. They were obsessed by class in the 1920's, and imposed this preoccupation on Soviet citizens. Paradoxically, however, a great many of those citizens had no firm class identity: they had become déclassés as a result of the upheavals caused by revolution and civil war, the shattering of the old class structure, the expropriation of the old elites, and the rapid upward mobility of many lower-class Bolshevik supporters. Full class identification during NEP thus requires two readings of an individual's class position: before 1917 and after. Since there were material advantages in being classified "proletarian", and disadvantages to being labelled "bourgeois" (or "kulak"), Soviet citizens often disguised their social origins, and invented or revised personal histories to enhance the class image they wished to project. 


\section{SUMMARIES OF ARTICLES}

The Stalinist Economic System facing the War

J. SAPIR

The impact of war-years (1941-1945) upon the Soviet system could not be overrated. Harsh and wild those years also were a period of profound and far reaching transformation. Described as a kind of Mobilization Economy, Soviet economy as a matter of fact had to be demobilized to survive this ordeal. This process, soviet leaders had no choice but to implement or perish in 1942, was actually the first step out the stalinist way and an harbinger of reforms and Perestrojka to come.

The Developed World's Three Agricultural Revolutions:

Yields and Productivity from 1800 to 1985

P. BAIROCH

This study, based on the elaboration of new data series, analyses the historical evolution of different agricultural yields and (labor) productivity. It highlights the specific characteristics of each of the three agricultural revolutions. The first (1700$1850 / 70)$, despite its moderate character, constituted a fundamental break with the past because in the space of 6 to 8 decades, productivity increased as much as in the preceding 8 to 9 millennia. The second agricultural revolution (1850/70-1936/50), brought about by mechanization and the development of artificial fertilizers, witnessed the beginning of the decline in the absolute number of agricultural workers, and an acceleration in yield growth, but little change in the rhythm of productivity growth. The third agricultural revolution (1936/50-1985) constituted a fundamentally new break, yields and productivity growing 4 to 5 times faster than before.

Bankruptcies and Economic Crises in 19th Century France

L. MARCo

The economic role of the bankruptcies brought on by the crises which shook the 19 th century was three-fold: they led to the detection of management errors, eliminated fragile firms, and paved the way towards subsequent recovery. Economic theories have emphasized the regulating function of bankruptcies, but historians concerned with these events have not compared the theory of regulation with the available data. That is what has been attempted here.

The Danube area, making up about 500,000 square kilometers, was characterized by slow demographic growth between 1500 and 1700, and sudden acceleration thereafter. This urbanization phenomenon is examined here at three historical moments using city population figures, the two tools of analysis being rank-size distribution and urban pyramids by large regions. The Danube area presents a certain unity for the first time when Vienna becomes its true capital, but its other particularity-the relative importance of small towns-seems to work against unification. The urbanization process was not linear, corresponding in Bohemia and Austria to the opening up of towns, whereas in Hungary-especially in the great plains-to their being closed off; the process thus repeated, though at a later date, the stages of Western Medieval development. 
In the course of the past thirty years, many studies have been devoted to the "Mycenaean colonization" of Cyprus. The problem is a considerable one, and the stances adopted are more contradictory than certain widely read publications would lead one to think. For many years it was thought that Mycencean communities were established on the island as early as the 14th century B.C. But the extraordinary boom in Cypriot archeology has made a profound impression, and most researchers today rule out any serious Mycenoean presence before the beginning of the 12th century B.C.. Faced with the massive destruction (at times attributed to the Dorians) which occurred in Greece at the end of the 13th century B.C., the Achoens are thought to have taken refuge in Cyprus where they ensured the survival of part of the Mycencean heritage. But archeological data and Near-Eastern written evidence reveal a far more complicated historical picture. Their examination, however, leads above all to illuminating the central role, in all such historical reconstructions, occupied by Homer's poetry and foundation legends relating to Cypriot centers. The centrality of epics and legends is hardly justifiable when one considers the nature of epic poetry and the speculative tendency dominating ancient historiography concerning the distant past.

The Way They Rewrite History

J.-F. Fitou

A careful examination of P. Gaxotte's Le siècle de Louis XIV shows that the book is a partial plagiary of Lavisse's Louis XIV (12.81\% of the former coming from the latter). Now why did a monarchist historian crib material from the masterpiece of French republican historiography? Similar ways of writing history brought the two men together, despite the political divarications which separated them. At times Gaxotte copies part of Lavisse's text, blending it into his own, while at others he borrows Lavisse's facts, changing but his conclusions to better fit his own political purposes. But plagiary betrays both historians' adherence to a common conception of historiography. This conception presents the past as a simple warning for the present. History is nothing but an utilitarian science intended for the prince's moral improvement. For Lavisse and Gaxotte, the Truth, the Right, and the Good loom up out of the past, but they pay no particular attention to bringing the past itself to light. 
Tous droits de traduction, d'adaptation et de reproduction par tous procédés, réservés pour tous pays.

La loi du 11 mars 1957 n'autorisant, aux termes des alinéas 2 et 3 de l'article 41 , d'une part, que les « copies ou reproductions strictement réservées à l'usage privé du copiste et non destinées à une utilisation collective »et, d'autre part, que les analyses et les courtes citations dans un but d'exemple et d'illustrations, « toute représentation ou reproduction intégrale, ou partielle, faite sans le consentement de l'auteur ou de ses ayants droit ou ayants cause, est illicite » (alinéa 1er de l'article 40 ).

Cette représentation ou reproduction, par quelque procédé que ce soit, constituerait donc une contrefaçon sanctionnée par les articles $\mathbf{4 2 5}$ et suivants du Code pénal.

Armand Colin éditeur. Paris - Dépôt légal : $1989-\mathrm{N}^{\circ} 6118-\mathrm{N}^{\circ} 2$, mai 1989 